\title{
Pathways to resilience: How drawings reveal preservice teachers' core narratives underpinning their future teacher-selves
}

Citation: Dinham, J., Chalk, B., Beltman, S., Glass, C., \& Nguyen, B. H. N. (2016). Pathways to resilience: How drawings reveal pre-service teachers' core narratives of their future teacher-selves. Asia-Pacific Journal of Teacher Education. doi: 10.1080/1359866X.2016.1204424.

Contact: Dr Judith Dinham, Curtin University. j.dinham@curtin.edu.au

\begin{abstract}
:
For this study of teacher-identity, which is part of a larger research project on teacher resilience, preservice teachers were invited to draw 'the kind of teacher you hope to become'. In this, our study recognises drawing as a semiotic system of meaning-making and communication. The drawings were examined, in terms of the 'stories' they told (Siegal, 1995).

Using an emergent design approach to the data (Charmaz, 2008), drawings were synthesised into categories that were distilled into theme clusters. A hermeneutic reading revealed the core identity narrative underpinning each teacher-identity story. This story was told in socio-cultural terms, or constructed around functioning at work or couched in terms of personal validation and achievement.

These core identity narratives signal what 'matters' to preservice teachers' sense of their teacher-selves. Since there is an observed correlation between teacher-identity and resilience, knowing what matters is a helpful basis for building resilience.
\end{abstract}

Keywords: teacher-identity, resilience, drawing, narrative, preservice teachers 


\section{Introduction}

The formation of teachers' identities is an expanding area of research interest (Beijaard, Meijer \& Verloop, 2004) because relationships have been shown to exist between teacher-identity and teaching effectiveness, teacher resilience, teacher retention and other teacher-related qualities (Beltman, Mansfield, \& Price, 2011; Chang-Kredl \& Kingsley, 2014; Day \& Gu, 2010; Day, Kington, Stobart \& Sammons, 2006; Day et al, 2007; Hong \& Greene, 2011). Within this body of research, the area of particular interest to our research group is the way the process of teacher-identity formation contributes to developing resilience and sustaining preservice teachers in their studies (Brand \& Dolloff, 2002) and through their years as novice teachers (Bennett, 2013; Harfitt, 2015; Johnson et al, 2015).

In social constructivist terms, identity is understood as being the different ways we view and present ourselves in different contexts within a matrix of historical, cultural, political and social forces and influences (Akkerman \& Meijer, 2011; Alsup, 2006; Curwood, 2014). Identity can be conceptualised as "stories to live by" (Clandinin, Downey \& Huber, 2009, p. 141) or as "those narratives about individuals that are reifying, endorsable and significant” (Sfard \& Prusak, 2005, p. 16). Hence, identity formation is not a trajectory to an end point but rather, an ongoing discursive process that is dynamic, complex, negotiated and contingent (Beijaard, Meijer \& Verloop, 2004; Chong \& Low, 2009; Day, Sammons, Stobart, Kington \& Gu, 2007).

Pearce \& Morrison (2011), with reference to the work of Bullough (2005) and Harré \& van Langenhove (1999), make the point that while identity is socially constructed, ongoing and multidimensional, it does have two distinct formations personal and public. Public identities, what Bullough (2005) calls 'situational' identities, are the ways we present ourselves in different contexts. Meanwhile our personal or 'core' identity (Bullough, 2005) is "a continuing feature of our point of view in the world [that is] connected to our sense of personal agency” and 'persists' behind the public identities (Pearce \& Morrison, 2011, p.49). This understanding is important for our study, as is the fact that identity formation also includes "a conception of one's potentiality” (Baumeister \& Muraven, 1996, p. 406).

In the ongoing process of professional identity formation, the preservice and novice years are recognised as a particular time of vulnerability for teachers (Bloomfield, 2010 as cited in Shann, Germantse, Pittard, \& Cunneen, 2014, p.90). In view of the relationship that has been shown to exist between professional identity, resilience and retention of beginning teachers (Howard \& Johnson, 2004; Moon, 2007; Pearce \& Morrison, 2011), effective ways of supporting preservice teachers in their identity formation is a concern for teacher educators (Bennett, 2013; Hamman, Wang \& Burley, 2013; Izadinia, 2012; Lu \& Curwood, 2015; Mansfield, Beltman, \& Price, 2014; Shann, Germantse, Pittard, \& Cunneen, 2014; Walkington, 2005).

As teacher-educators ourselves, and in the context of our overarching research project on teacher resilience, we proposed that inviting preservice teachers to draw 'the kind of teacher you hope to become' could reveal information about their professional 
identities not revealed through other data gathering processes; and that this would inform our knowledge base. This paper reports on: our study; our application of an emergent design to examine visual images as data; and our process of interpretation.

\section{The study}

In this study, 126 participating first year preservice teachers enrolled in Early Childhood, Primary and Secondary Bachelor of Education degrees at an Australian university were invited to draw 'the kind of teacher you hope to become'. Their drawings were treated as graphic narratives (Wright, 2007) and examined through a process of trans-mediation and semiosis (Siegal, 1995) in terms of the stories they told. This brought to the surface three identifiable themes that underpin the stories and reveal each preservice teacher's underlying values (what matters). With reference to Pearce \& Morrison's (2011) identification of two distinct formations of identity - public and personal - we posit that the emergent themes represent the personal or core identity story persisting behind the public identities. Within the dynamic space of teacheridentity formation, 'what matters' in a person's constitution of self is potentially a basis for building resilience - the capacity to adapt and persist. For example, if relationships are what matters to an individual, then having good relationships with students and colleagues will be a key factor in their professional identity formation and hence their resilience.

Our use of visual methodology for this study recognises (1) the dialogic of the visual image (Bal, 2012); (2) that images reveal information not necessarily gained from written and verbal sources (Weber \& Mitchell, 1996); and (3) that not all knowledge can be translated into words (Thwaites, 1999).

Our application of an emergent design generated data sufficient for an interpretative discussion. We are satisfied a coherent synthesis (Huber, 1995) has been reached sufficient to make a contribution to the field. We also make clear that this study is a "first level analysis" (Bober, 2011, p. 67) foreshadowing future research. Teacheridentities will evolve through experience and exposure, so in future research it will be important to examine whether the theme of each individual's teacher-identity story is sustained and persists even as the teacher-identity evolves. This would confirm that the drawings do in fact reveal the personal (core) identity narrative persisting and underpinning the public (situational) identity stories.

\section{Visual methodological approaches to examining preservice teacher-identity development}

A number of qualitative research studies of preservice teachers' professional identity have used participants' drawings as sources of data (Bennett, 2013; Coughlin, 2001; Freer \& Bennett, 2012; Glass, 2011; Katz et al, 2011; Leitch, 2006; Utley \& Shoalwater, 2007; Weber \& Mitchell, 1996). 
Freer and Bennett (2012) used drawings to determine whether future teachers' subjective identities (the way they see themselves) and their objective identities (the way others see them) were congruent. In a second study conducted over a semester, drawings of the 'teaching situation' and journal entries revealed a more context-based understanding of the role of the teacher and led to participants' improved confidence about becoming teachers (Bennett, 2013).

In a case study about becoming a primary teacher (Glass, 2011), drawings in combination with interviews and graphing revealed beliefs preservice teachers had about teachers and teaching. The early drawings showed an initial 'ideal' situation and later drawings showed greater complexity and understanding of the contexts within which teaching occurred.

In the context of a voluntary after-school science teaching project, preservice primary school teachers made drawings of themselves teaching science, and students learning science. The researchers reported a significant shift over the duration in the representation of identity from a teacher-centred role to a more student-centred one (Katz, et al, 2011).

\section{Visual methodology and the present study}

In studies that use visual methodologies, the images are ascribed different status depending on the approach adopted. Images can function as inventories of material reality, or representations of social identity, or objects whose meaning is negotiated conjointly with textual data, or by interview with the creator (Rose, 2012). Images can fulfil other useful roles in the research context. For example, photographs have been prompts for 'elicitation' of information from the person who took the photograph (Rose, 2012, p. 312). Such processes are recognised as having merit in pedagogical contexts too. For example, Brand and Dolloff observed that using drawings as starting points for reflection and class discussions, "can be a valuable entry into the attitudes, beliefs, aspirations and even fears of beginning music education students” (2002, p. 26).

Drawing's agency in this study

In the semiotic tradition, drawings are understood as texts - systems for exploring, constructing and communicating meaning (Brooks, 2005; Kress, 1997; Wilson, 1985; Wright, 2010), and all drawings have their own agency (Dinham, 2014; Rose, 2012).

Using research participants' drawings as sources of data is a distinct category of visual research methodology (Rose, 2012; Theron, Mitchell, Smith \& Stuart, 2011). In this context, the final meaning of the drawing is often determined or confirmed by the written and oral contributions. This is to address the expressed concern that if images are not contextualised by words there is the risk that they will be obscure, or their meaning misinterpreted (Rose, 2012).

The methodological literature implies that images are unreliable. However, we understand all forms of expression and communication - embodied, gestural, visual, 
aural and linguistic - as texts that freight meaning. As hermeneutics reminds us, this 'meaning' is modified by context and subject to interpretation. Therefore drawings are probably no more or less reliable than other forms of communication or texts. In fact, Wilson contends that "the graphic configurations of a culture are as conventional, regular and predictable as the words of a given language” (1985, p. 92). Further, in the multiliteracies paradigm, drawings are recognised as 'speaking for themselves' and not requiring the intercession of explanatory words (The New London Group, 1996). Since drawings are efficacious in communicating perceptions not necessarily understood, articulated or censored by participants (Weber \& Mitchell, 1996), we concur with Keats (2009) that they be carefully considered in their own right, separate from the textual data.

In our study we privilege the drawing and focus on 'reading' the drawings as they are presented, without calling on mediating explanations. We also recognise that the visual (and performing) arts offer opportunities for 'trying on' identities in the interstitial spaces (Chalk, 2007) where "the forces that shape who we are in the process of becoming” (Kamanos Gamelin, 2005, p. 184) may be identified and the consequences realised. Hence in this study we move beyond our initial content analysis where items in the drawings were catalogued to facilitate other data gathering processes (Beltman, Glass, Dinham, Chalk, \& Nguyen, 2015), to reviewing the drawings as articulations of meaning in their own right.

If a picture is worth a thousand words it is because "the laws that govern articulation of meaning in the arts are different from the laws of syntax that govern language” (Wright, 2007, p. 1) so the interpretation of the drawings for this study was undertaken by the artists/arts educators on the research team who drew on their arts background and experience to 'read' the drawings.

\section{The nature of the data - recognising different drawing modes}

In the research context, the participants' technical drawing skills and the aesthetic quality of their drawings are not a primary concern. However Greig, Taylor \& MacKay (2007) caution that technical factors (e.g. children's fine motor control) may have a bearing on the information conveyed. The caution is instructive since different modes of representation have intrinsic features that should be considered when interpreting drawings. Three identifiable modes relevant to this study are

- Schematic drawings

- Graphic notations

- Realistic/perspectival drawing

Drawings do not always fall into one of these categories exclusively so these elements have to be interpreted separately. 


\section{Schematic drawing}

It is the case that, with several caveats, children's early scribbles typically and consistently evolve over a period of years through recognisable developmental stages (Gardner, 1980; Lowenfeld \& Brittain, 1987; Malchiodi, 1988). So-called 'schematic drawing' is one of these stages, and is known to persist through adulthood where this type is also referred to as 'canonical' drawing (Matthews \& Adams, 2008). In these drawings, symbols are habitually and consistently employed as 'signs' for signifying objects e.g. stick figures for people, irrespective of the specific physical features of the object being drawn. Therefore when reading these drawings, a caution is to not assume that the inevitable upward curving line for a mouth represents a happy demeanour. This is because in a schematic drawing, the 'smiley face' is a 'sign' or stock 'icon' for a face and does not automatically denote a happy disposition. (The pervasive use of emoticons in everyday digital communications may modify this in future years).

Another distinctive feature of 'schematic drawings' is that the significance of individuals and relationships is consistently articulated through size and placement: children will draw themselves larger than adults or, in one example, obscure a sibling rival behind a bush when drawing the family group (Day \& Hurwitz, 2012).

Significance can also be represented by detail. For example, in some drawings in the study, the schema adopted for oneself as the teacher was a circle with a face whereas the children were represented by faceless circles. Alternatively some participants drew themselves as a face and body but represented children as simply heads without bodies. As with children's schemas, the person creating the drawing is representing the relative significance (to themselves) of that which is being signified.

Importantly, in relation to this study, a simple and stable schema that "seems to satisfy the basic needs in pictorial representation” (Kindler \& Darras, 1994, p. 10) emerges in the early primary school years and, without the intervention of art education, persists into adult life (Kindler \& Darras, 1994; Matthews \& Adams, 2008). Many drawings in our study were of this type.

\section{Graphic notations}

Graphic notations are drawings in which simple geometric shapes, e.g. circles or crosses, are used to represent objects. These shapes invariably require written labels or a key to inform the viewer that, for example, the cross represents the child. In another type of graphic notation, the symbols are pictorially based and/or widely used, so the interpretation does not require additional information. For example, one drawing in the study depicted a mathematical equation organised with the insertion of plus $(+)$ and equals (=) symbols between a question mark, a head shape showing the brain and a light bulb. This can be easily interpreted as showing that applying one's thinking to a problem creates a solution.

For drawings that are essentially graphic notations, spatial dynamics are not reliable presentations of physical proximity. The space on the page is often used to 
separate out different events that contribute to the story rather than to show, for example, where the teacher is positioned in the classroom space.

\section{Realistic/perspectival drawings}

Realistic or perspectival drawings represent the visual world by considering the particular appearance of objects and their relative positions in a three-dimensional space. In these drawings, which are developmentally more advanced than 'schematic drawings', one can expect to see individualised appearance in hair styles and clothing choices, as well as the use of diminishing size, overlapping shapes and convergence of parallel lines to place objects in a spatial relationship. The relative size of objects is more carefully controlled and therefore the subliminal messages about significance conveyed by size in 'schematic drawings' do not apply here. Likewise, in these drawings, a smiling face can be interpreted as representing the disposition of the individual.

\section{Methodology}

This study sits within a social-constructivist paradigm (Berger \& Luckmann, 1966) and draws on grounded theory and hermeneutics (Caputo, 1987; Gadamer, 1994; Willis, 2002). An emergent (inductive) design is employed to work the data.

In the hermeneutical tradition, the drawings are approached as texts that freight meaning and require interpretation. Mindful that the context shapes (multiple) realities/meanings and that knowledge is predisposed to interpretation, the research context and question/s provide the filters or lens through which the data are approached and interpreted as stories of a future teacher-self (Rose, 2012). In this process the subjectivity of the researchers as well as the participants, and their roles in the coconstruction of meaning, are acknowledged as an inevitable part of the outcome (Charmaz, 2008; Hayes and Oppenheim, 1997).

The reliability of this approach is supported by the presence on the research team of arts educators experienced in visual arts and storying through drama. We have been careful to 'read' the story in the context of the different drawing modes used by participants in the study. The 'reading' of the drawing carefully avoids a psychoanalytical inscribing of symbolic meaning that belongs in the therapeutic context.

\section{Data collection}

Approval for this study was gained from the University Ethics Committee, and informed consent granted by participants. The participants $(n=126)$ were drawn from first year preservice teachers in the Early Childhood, Primary and Secondary programs of a Bachelor of Education degree at an Australian university. Reassurances that drawing skills were not being judged were given before students were asked to, 'Draw the kind of teacher you hope to become and then, on the reverse describe in words what you have drawn.' 


\section{Data patterning and coding: an emergent design}

As interpreters we understand that our interpretations are on display as we are engaged in both the representation of our data analysis and 'self-representation' (Chenail, 1997; Denzin, 2009). Aware of our theoretical sensitivity we were mindful to guard against over pre-occupation with any prior theory (Denzin, 2004) that may obstruct the visibility or emergence of embedded meanings in the drawings. We maintained data patterning and coding procedures and made no attempt to bracket (Gearing, 2008).

Given the inherent constraints, contradictions and ambiguities in the drawings (as in any text), a feedback and feed-forward looping, with ongoing attention to what the data 'grant' (the hermeneutic cycle), was adopted to maintain constancy and consistency throughout the interpretation process. As Bryant and Charmaz suggest, "the iterative process of moving back and forth between empirical data and emerging analysis makes the collected data progressively more focused and the analysis successively more theoretical” (2007, p. 1). The data 'patterning' undertaken through this process of induction, insightful invention, discovery and disclosure (Van Manen, 1990) led eventually to the identification of themes.

\section{Working the data}

\section{Stage 1}

When the drawings completed by the Early Childhood/Primary cohort $(n=82)$ were received and numbered (de-identified), the first process involved 'listening to the drawings' and describing what we learned from them. In time, patterns in the type of information became discernible.

With reference to Algers (2009) organising principles, we consistently found we could read information about disposition, personal attributes, relationships, the way schooling/education was perceived, learning context and the nature of pedagogy. These became the headings in a table created to code features and attributes in each drawing. The table was used to manage the data and avoid the risk of infinite interpretations and dilution of the information and stories to the extent that the person who drew the image would be rendered invisible.

Working separately to increase the veracity of the process, the aim was not to fill every cell in the table but rather, to see where information gleaned from the drawings could be placed; whether the table captured all the information; and whether the nascent categories were reliable discriminators and information didn't bleed across them.

While participants were asked to add written descriptions of what they had drawn on the verso, many wrote and drew on the same side of the paper and often the text was interwoven with the drawing. In accordance with the visual methodology principle of giving due consideration to the primacy of the drawings when coding (Keats, 2009; Rose, 2012), we determined at this stage of the process, to only reference 
text that labelled graphic symbols. We reviewed the other written descriptions in Stage Two as part of testing the categories.

\section{Stage 2}

The second stage involved appraising the drawings holistically in terms of the primary 'story' and categorising the different types of teacher-self presentations. A focused coding process synthesised and distilled the emerging patterns into nine categories of teacher-self representations.

Before a shared review and discussion, the categories were tested by two independent re-codings and reviewed against the textual data. The categories proved sufficiently robust to be functional: all drawings could be synthesised into them except for two that remained uncategorised because they were minimal to the extent they fell outside the scope of this study. These were cleaned from the data.

\section{Stage 3}

The categories were tested with a new cohort: the secondary preservice teachers $(n=44)$. Consistent with the nature of an emergent design, the process was open to the possibility that new categories may emerge, however, this did not occur. With the secondary students' drawings distributed across seven of the nine categories, we determined the categories were broadly applicable and effective in capturing the breadth of likely stories, regardless of educational sector. With 126 respondent overall, each category had at least two drawings within it.

\section{Stage 4}

Discussions with the research team identified that nine categories was potentially unwieldy. Since every response is significant we chose to create theme clusters (see below) rather than eliminating poorly populated categories from the analysis.

\section{Credibility of method/validity}

The research team claims an intimate familiarity with the topics of teacher-identity, qualitative research and arts-based research that uses many text modalities, including performance and artworks as data.

The amount of data and the transparency of the data analysis are trustworthy and provide sufficient information and insight into the topic on which to ground the findings and claims.

We substantiate credibility using Jensen's (2008) categories of time, angles, colleagues, triangulation and member checks.

Sufficient time was given to contacting participants, gaining informed consent and data collection. There was also time between the research formalities and the enactment of the data gathering for participants to 'digest' the expectations. A generous amount of time was also set aside for participation. 
Those analysing the data were experienced arts educators who understand that visual data, by its nature, avoids closure. Their perspective (angle) enabled them to approach the data with skill. At the same time, foregrounding their subjectivity, they were careful to ensure that they made no attempt to bracket their theoretical and practical experiences in education and the Arts, i.e. their worldview when reading the drawings.

Other members of the research team reviewed and critiqued the data analysis. Further strategies were proposed to refine the coding.

The data gathering sources were the drawings and written descriptions. Since the written data were analysed as 'stand-alone' data, this served in place of member checks to validate the coding of the drawings. The inclusion of text was not consistent across the group and reference to it can only be seen as sampling. For a first level analysis this is not seen as an impediment.

Alger's (2009) organising principles were a point of reference and useful guide for the initial coding. Consistent with an emergent design, other features emerged and were added. The categories created from this process were then checked against the original 'drawings' and 'drawings with descriptions' analysis. To consolidate the data analysis there was a further triangulation of the themes in which we did a 'double check' of each image against its original theme allocation.

\section{Emergent categories and themes}

The nine categories of teacher-self presentations and distributions of respondents are outlined here. We underscore that some elements in the picture may be common across categories but the categories come from reading 'the story' told in each picture. The three theme clusters into which the categories were distilled are described with illustrative examples.

\section{Categories of teacher-self presentations}

(1) What I offer. The drawing highlights my personal and professional attributes. E.g. I am organised and hard working. I feel a degree of personal responsibility for my performance and want to show what I can offer. In this, there is an implied sense of personal responsibility for 'making the grade' as a teacher.

(2) Us together/relationships. The drawing is picturing the socio-cultural dynamics of the schooling experience created for the children. E.g. The children and teacher pictured in a circle holding hands. Drawings in this category are supported by comments such as ‘children feel secure and supported' or accompanied by words that place value on qualities like praise, equality, happiness.

(3) The teaching event. Picturing myself engaged in a teaching process (with little reference to the physical environment). This is consistently depicted as instruction - the teacher as instructor: I am knowledgeable in content and able to instruct students. A concomitant reading is that education is content driven. 
(4) The learning location. Picturing my students and myself in the physical learning environment. In these depictions, there is a strong conceptualisation of contextualised learning and awareness of the influence of the environment on learning. The classroom as 'silent teacher' or 'learning as experience' is strongly suggested. The teacher may be represented as the primary agent or orchestrator of learning but not the sole agent. Two subsets are drawings where only the teacher is present and drawings where no-one is present in the learning environment.

(5) Education as a multi-dimensional undertaking. The picture purposefully captures different facets of the profession such as values, socio-cultural dynamics, organisation requirements, nature of learning.

(6) The quality of what takes place. The drawing highlights the nature and value of the educational experience above other dimensions. E.g. Children will have challenging lessons; the learning will be fun.

(7) Having an impact. The drawing is depicting my desire to 'make a difference'. It generally describes my teacher-self by projecting into the future or referring to goals and achievements beyond the classroom. Such drawings may be supported by terms such as 'mission' or 'sense of vocation'.

(8) Teacher-centric. The focus in these drawings is on how I am regarded by others. Such drawings are also supported by comments like 'children respect me' or 'I am the centre of attention'.

(9) Lifestyle. The drawing focuses on how teaching fits into my life. Such drawings have associated comments like 'I will have separation between my work and home life'.

\section{Distribution across teacher-self categories}

The data were cleaned and distributed across all descriptive categories. The Early Childhood/Primary cohort $(\mathrm{n}=80)$ in the data set is nearly double the size of the Secondary cohort $(n=44)$. For comparison, the distribution across the categories is expressed in rounded-up percentages. Categories three (the teaching event) and four (the learning location) were the most frequent overall across both cohorts. Most Secondary students' stories were in Category three and most Early Childhood/Primary students in Category four. 


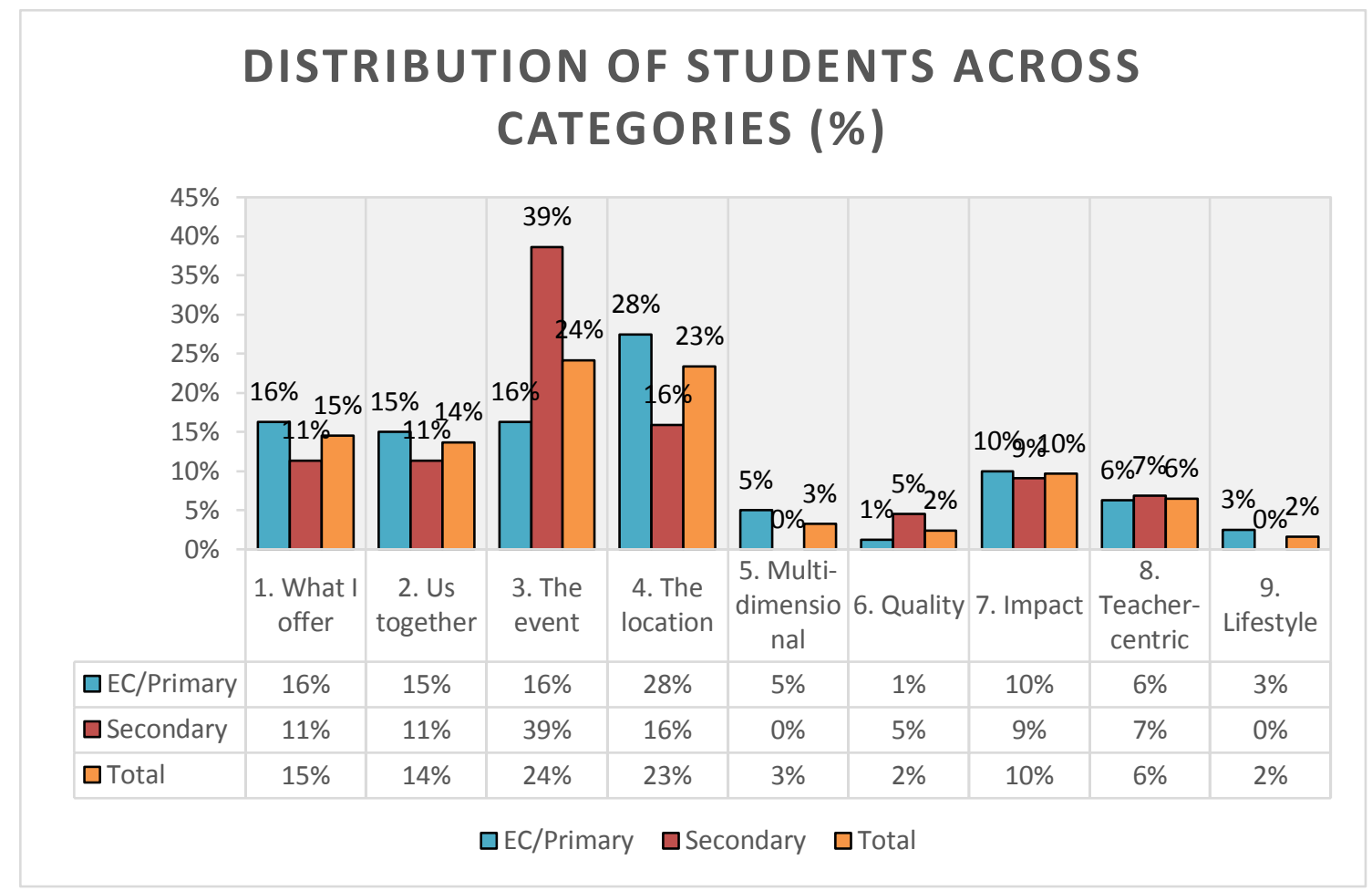

Table 1. Distribution across teacher-self categories

\section{Emergent theme clusters}

The nine categories fall into three distinct theme clusters.

1. People and relationships: We are here (Categories 1 and 2). The socio-cultural dynamic, expressed in terms of social influence and agency, is foregrounded. The focus is on individual qualities, well-being and the interpersonal relationships of the 'players' in the social space.

Presentation of self through the choice of clothing is a notable feature of this cluster. The choices vary from very conservative to casual work attire but there is a clear recognition that clothing conveys messages about self.

For nearly one third (31\%) of Early Childhood/Primary preservice teachers and $29 \%$ of all respondents, this is the core theme in their teacher-identity story. 


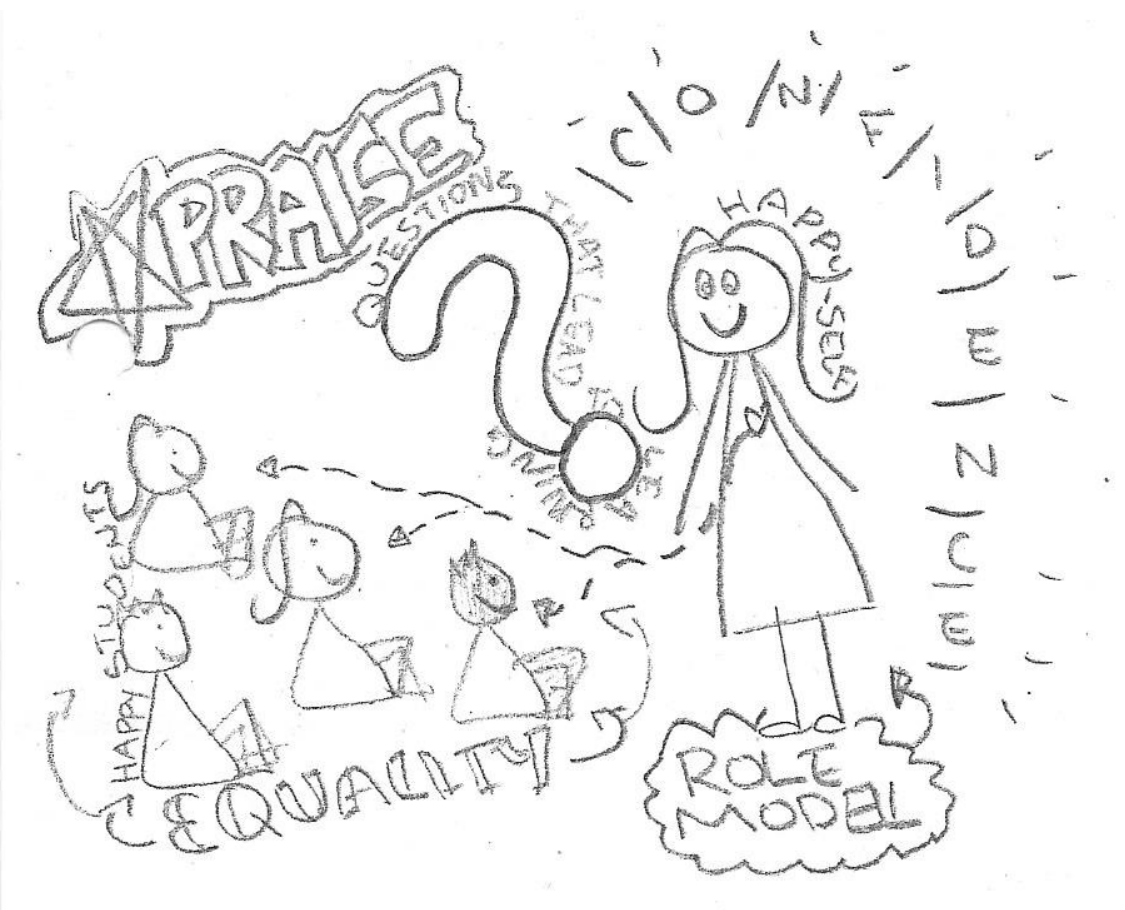

Figure 1. Illustrative example. Drawing 167P

The drawing of teacher and children is wrapped in words describing qualities of the relationship. The teacher offers herself as a role model and loving person. The direct smile and gaze, open stance and inclusion of "Happy self” and "C/O/N/F/I/D/E/N/C/E/" in the shape and position of a mandorla convey how self-confidence and a happy demeanour are valued. The dotted lines from her drawn heart to the children signify that caring is an important and significant constant in the school day. The centrality of children's well-being is highlighted by the labelling that encircles the group of children: "Happy students" and "Equality” in block letters with arrows connecting to each child.

This drawing is compact and enclosed with words and symbols, including ones that highlight praise and learning (expressed as "questions that lead to learning”). Relationships and children's wellbeing are to the fore. This respondent expresses her identity in terms of her disposition and ability to create a warm and loving environment for the children.

2. Educational work: The educational work I am here to do (Categories 3, 4, 5 and 6).

In this cluster the teacher-identity is conceived in terms of the individual being an active agent at work, engaged in work and managing that work. How this work is conceived, varies. Consistently, the school or classroom is the setting where the performances of identity are constructed and displayed (Goffman, 1959). This is the largest cluster and there are several sub-themes within it, but in each case, the primary story is told in terms of 'functioning at work'. Fifty-two per cent of respondents are represented in this cluster. 


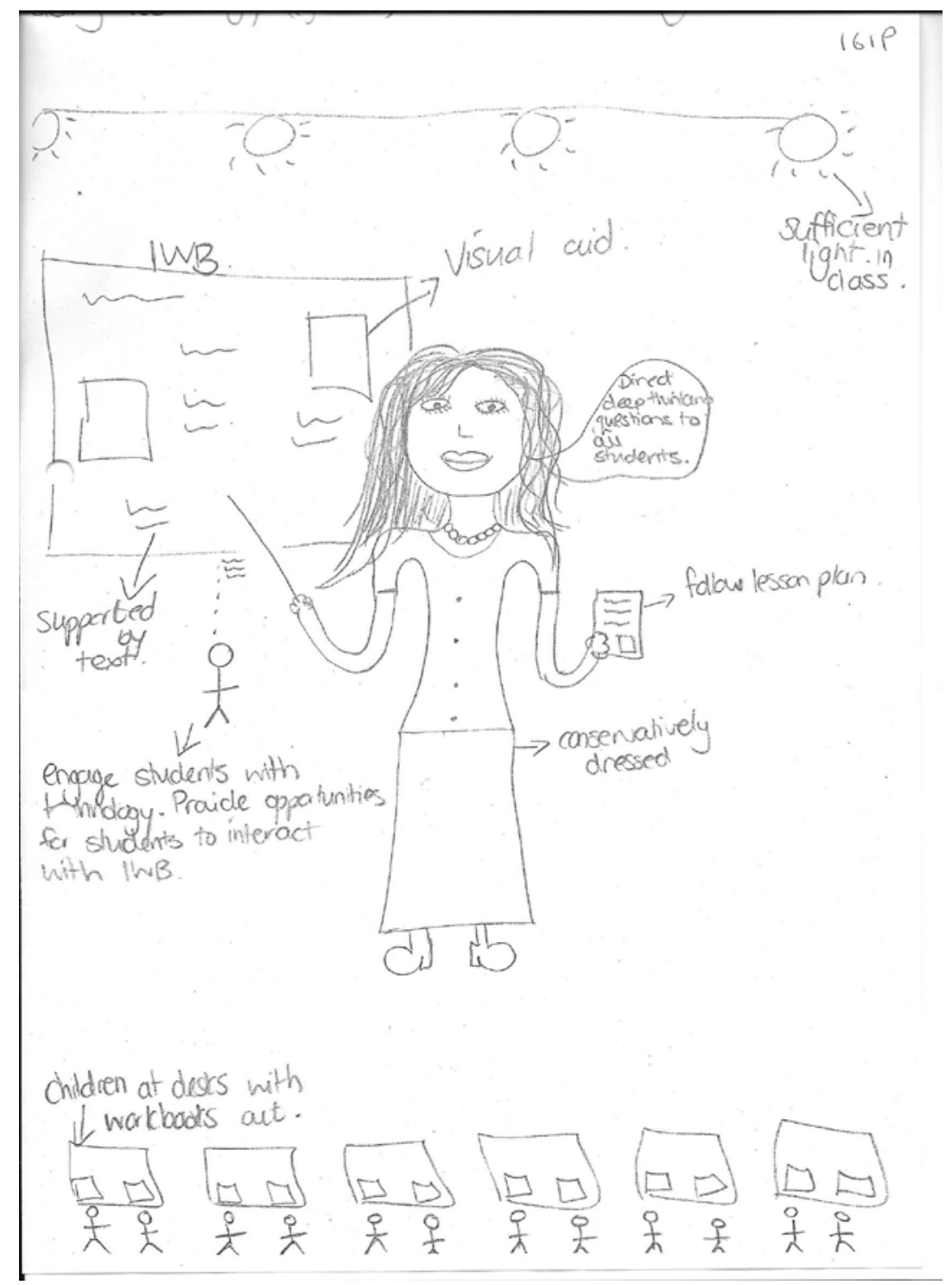

Figure 2. Illustrative example. Drawing 161P

In presenting herself at work, the respondent shows she is aware of her position or status: she has drawn herself in conservative dress (reinforced in the label), she is centrally located, drawn in some detail, and she holds a pointer in her hand. Children are represented as an orderly row of small stick figures at the bottom of the page. In this, the teacher presents herself as commanding the learning space and as the primary agent for learning (the conductor). She holds a document labelled "follow lesson plan" and her speech bubble says "direct deep thinking questions to all students”. These features, other text and visual symbols - such as the interactive whiteboard - convey that she 'knows' what her work entails and she is there to do it.

3. Personal validation: What teaching does for my sense of self (Categories 7, 8, and 9).

In this cluster teacher-identity is constructed in terms of what teaching means for my sense of self; and how this profession 'will make me feel good about myself'. This is 
generally expressed in terms of goals - whether the goal is to make a difference or to maintain a work-life balance. These goals may be visualised around children's wellbeing or the quality of the educational program, but in the end, the teacher-self needs to be reassured that their engagement in the teaching profession will provide personal satisfaction and a sense of purpose or achievement. Eighteen per cent of respondents were in this theme cluster.

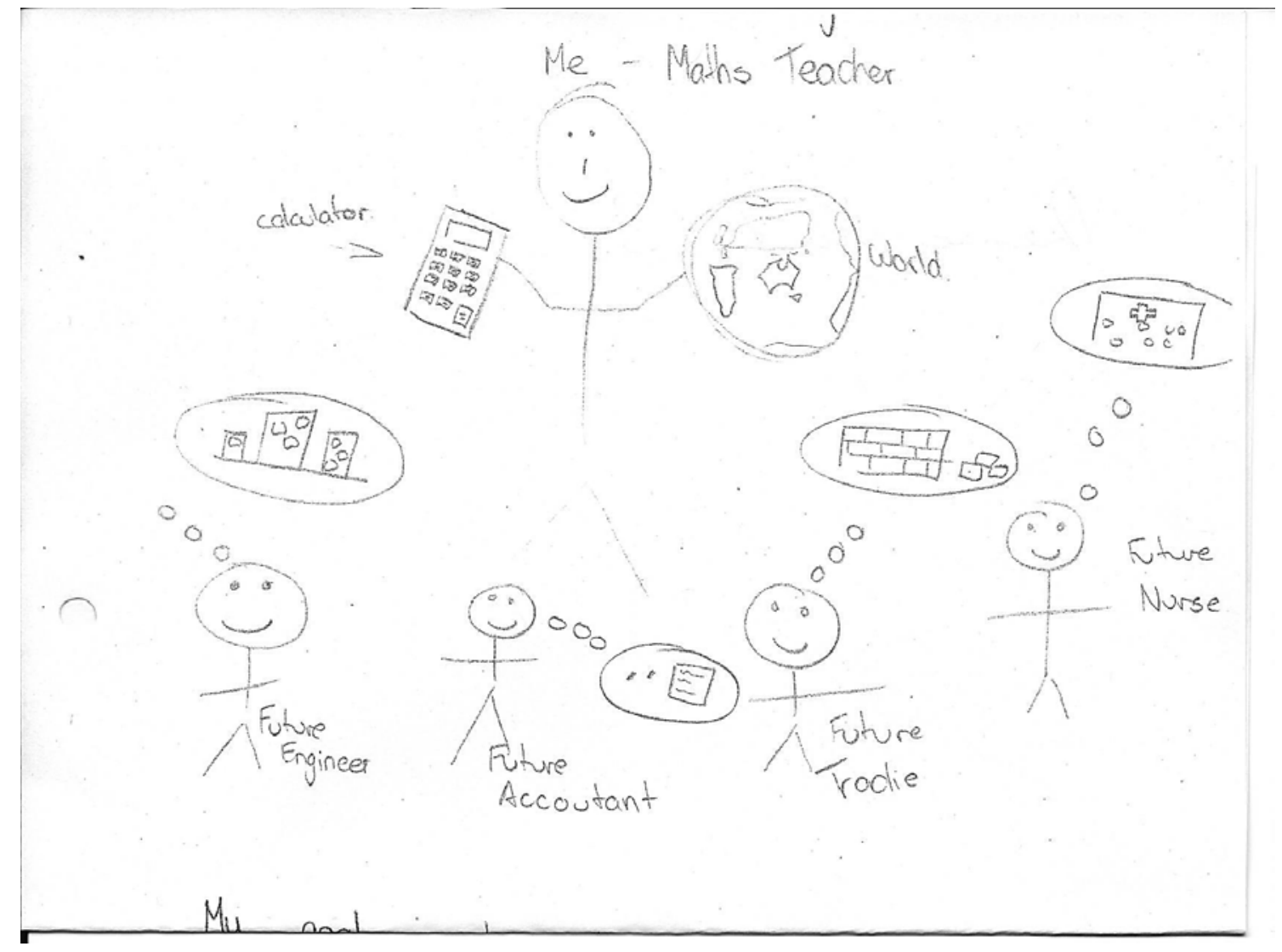

Figure 3. Illustrative example. Drawing 227S

This drawing by a future Secondary maths teacher highlights the importance of maths in many occupations. He/she is not engaged in teaching but looks to what $\mathrm{s} / \mathrm{he}$ will achieve through teaching to 'make a difference' in terms of students' post-school lives - in their future occupations. The teacher holds a calculator and globe of the world that shows how s/he conceives the role of teacher in terms of future outcomes (achievements) and the wider context. The figures of children are labelled 'Future Engineer”, Future Accountant”, “Future Tradie”, Future Nurse”.

\section{Conclusion}

This study is part of research about teacher-identity, which sits within a larger research project on teacher resilience. The decision to adopt a visual research methodology and ask participating preservice teachers to 'draw the kind of teacher you hope to become' was predicated on understanding drawings as semiotic systems of meaning-making and communication that can reveal information not necessarily gained from text or verbal sources (Rose, 2012; Thwaites, 1999). We anticipated that this would contribute to our knowledge base. 
In this paper we have outlined how we used an emergent design to 'hear' and 'see' the stories told in the drawings; and how we were guided by the iterative process of a hermeneutic approach to work the data to reach a point of synthesis. (Given the multiple, embedded meanings of images, a point of saturation was not, nor should be, possible.) We have made clear that throughout the process we were attentive and mindful of situating the drawing as the author and authority. In this, we understood that the drawing mode adopted by the participant prescribes how the drawing 'speaks'.

We own the potential limitation of using the textual information in place of member checks as this aligned with our methodological assumptions; and we believe the data have been 'worked' sufficient to answer two questions:

(1) Have the stories been 'heard', i.e., have the researchers approached the data with respect for the authorial voice?

(2) Have the data been 'worked' sufficiently for categories and themes to emerge?

Our study revealed the core narrative (theme) underpinning each preservice teacher's story of identity: people and relationships, educational work or personal validation. Our contention is that each story's theme or core narrative represents the "relational boundaries within which [preservice teachers] form new professional identities” (Pearce and Morrison, 2011, p. 53) and is the foundation for their individualised 'becoming' their 'futured' teacher-identity.

As stated earlier, this study is a "first level analysis" (Bober, 2011, p. 67) foreshadowing future research, so our claims are provisional. Never the less, with an understanding that professional identity is a factor in developing and maintaining resilience our proposition is that differentiated approaches and experiences that address the nature of each individual's core identity narrative could be an effective way of supporting preservice teachers' situational or professional identity formation during this recognised period of vulnerability.

We have shown that drawing is one way by which 'stories' of 'becoming a teacher' can be made visible, named and foregrounded - and that the artefact (drawing) can reveal information not necessarily gained from text and verbal sources. In accord with Brand and Dolloff (2002) and Utley and Showalter, (2007), this process of drawing could be pedagogically constituted and preservice teachers' drawings become "sites for self-constitution” (Adams St Pierre, 2001, p.158). Having the opportunity to locate and name the core narrative for their 'future selves as teachers', i.e., to identify and name what 'matters', potentially facilitates preservice teachers' agency in developing and maintaining resilience.

\section{References}

Adams St. Pierre, E. (2001). Coming to theory: Finding Foucault and Deleuze. In K. Weiler (Ed.), Feminist engagements: reading, resisting, and revisioning male theorists in education and cultural studies (141-163). New York, NY: Routledge. 
Akkerman, S. F. \& Meijer, P. C. (2011). A dialogical approach to conceptualizing teacher identity. Teaching and Teacher Education, 27, 308-319.

Alger, C. L. (2009). Secondary teachers' conceptual metaphors of teaching and learning: Changes over the career span. Teacher and Teacher Education, 25, 743751.

Alsup, J. (2006). Teacher identity discourses: Negotiating personal and professional spaces. Mahwah, NJ: Lawrence Erlbaum Associates.

Bal, M. (2012). S-words. Journal of Visual Culture, 11(2), 145-148. doi: $10.1177 / 1470412912444187 \mathrm{~g}$

Baumeister, R. F., \& Muraven, M. (1996). Identity as adaptation to social, cultural, and historical Context. Journal of Adolescence, 19, 405 - 416. doi:10.1006/jado.1996.0039

Beattie, M. (2000). Narratives of professional learning: Becoming a teacher and learning to teach. Journal of Educational Enquiry, 1(2), 1-23.

Beijaard, D., Meijer, P., \& Verloop, N. (2004). Reconsidering research on teachers' professional identity. Teaching and Teacher Education, 20(2), 107-128. doi:10.1016/j.tate.2003.07.001

Beltman, S., Glass, C., Dinham, J., Chalk, B., \& Nguyen, B. H. N. (2015). Drawing identity: Beginning pre-service teachers' professional identities. Issues in Educational Research, 25(3), 225-245.

Beltman, S., Mansfield, C., \& Price, A. (2011). Thriving not just surviving: A review of research on teacher resilience. Educational Research Review, 6, 185-207. doi: 10.1016/j.edurev.2011.09.001

Bennett, D. (2013). The use of learner-generated drawings in the development of music students' teacher identities. International Journal of Music Education, 31(1), 5367.

Berger, P. L., \& Luckmann, T. (1966). The social construction of reality: A treatise in the sociology of knowledge. Garden City, NY: Anchor Books.

Bober, L. (2011). Visualising justice: The politics of working with children's drawings. In L. Theron, C. Mitchell, A. Smith \& J. Stuart (Eds.), Picturing research: Drawing as visual methodology (pp. 63-76). Rotterdam, Netherlands: Sense Publishers.

Brand, M., \& Dolloff, L. (2002). Fantasies and other romanticized concepts of music teaching: A cross-cultural study of Chinese and North American music education students' images of music teaching. International Journal of Music Education, 39(1), 17-30. doi: 10.1177/025576140203900103

Brooks, M. (2005). Drawing as a unique mental development tool for young children: Interpersonal and intrapersonal dialogues. Contemporary Issues in Early Childhood, 6(1), 80-91.

Bryant, A., \& Charmaz, K. (Eds.). (2007). The SAGE handbook of grounded theory. Los Angeles, CA: Sage. 
Bullough, R. J. (2005). The quest for identity in teaching and teacher education. In G. Hoban (Ed.), The missing links in teacher education design (pp. 237-258). Dordrecht: Springer.

Chalk, B. (2007). Sacred theatre as locus for women to reflect on identity (Unpublished $\mathrm{PhD}$ thesis). University of Western Australia, Perth, Western Australia.

Caputo, J. D. (1987). Radical hermeneutics: Repetition, deconstruction and the hermeneutic project. Bloomington, IN: Indiana University Press.

Charmaz, K. (2008). Grounded theory methods in social justice research. In N. K. Denzin \& Y. S. Lincoln (Eds.), The Sage handbook of qualitative research (pp.359-380). Los Angeles, CA: Sage Publications.

Chenail, R. (1997). Keeping things plumb in qualitative research. The Qualitative Report, 3(3), 1-8.

Chong, S. \& Low, E. (2009). Why I want to teach and how I feel about teachingformation of teacher identity from pre-service to the beginning teacher phase. Education Research Policy and Practice, 8, 59-72.

Clandinin, D. J., Downey, C. A., \& Huber, J. (2009). Attending to changing landscapes: Shaping the interwoven identities of teachers and teacher educators. Asia-Pacific Journal of Teacher Education, 37(2), 141-154.

Coughlin, M. (2001). See teacher draw: Exploring pre service teachers’ perceptions of teaching. Academic Exchange Quarterly, 5(3), 191-195.

Crosswell, L., \& Beutel, D. (2013). A bridge over troubling waters: A snapshot of teacher graduates' perceptions of their ongoing professional learning needs. AsiaPacific Journal of Teacher Education, 41(2), 144-158.

Curwood, J. S. (2014). Between continuity and change: Identities and narratives within teacher professional development. Teaching Education, 25(2). 156-183. doi: $10.1080 / 10476210.2012 .755159$

Chang-Kredl, S., \& Kingsley, S. (2014). Identity expectations in early childhood teacher education: Pre-service teachers' memories of prior experiences and reasons for entry into the profession. Teaching and Teacher Education, 43, 27-36. doi:10.1016/j.tate.2014.05.005

Day, C., \& Gu, Q. (2010). The new life of teachers. New York, NY: Routledge.

Day, C., Kington, A., Stobart, G., \& Sammons, P. (2006). The personal and professional selves of teachers: Stable and unstable identities. British Educational Research Journal, 32(4), 601-616. doi:10.1080/01411920600775316

Day, C., Sammons, P., Stobart, G., Kington, A., \& Gu, Q. (2007). Teachers matter: Connecting work, lives and effectiveness. New York, NY: Open University Press.

Day, M., \& Hurwitz, A. (2012). Children and their Art: Art education for elementary and middle schools $\left(9^{\text {th }}\right.$ ed.). Boston, MA: Wadsworth.

Denzin, N. K. (2004). The art and politics of interpretation. In S.N. Hesse-Biber \& P. Leavy (Eds.), Approaches to qualitative research. A reader on theory and practice (447-472). New York, NY: Oxford University Press. 
Denzin, N. K. (2009). Qualitative inquiry under fire: Toward a new paradigm dialogue. Walnut Creek, CA: Left Coast Press.

Dinham, J. (2014). Delivering authentic arts education (2 ${ }^{\text {nd }}$ ed.). Melbourne: Cengage Learning International.

Freer, P. K., \& Bennett, D. (2012). Developing musical and educational identities in university music students. Music Education Research, 14(3), 265-284. doi: 10.1080/14613808.2012.712507

Gadamer, H-G. (1994). Truth and method: 2nd Revised Edition (J. W. Weinsheimer \& D. G. Marshall, Trans.). New York, NY: Continuum.

Gardner, H. (1980). Artful scribbles: The significance of children's drawings. New York, NY: Basic Books Publishers.

Gearing, R. E. (2008). Bracketing. In L.M. Given (Ed.), The Sage encyclopaedia of qualitative research methods: Volume one. Los Angeles, CA: Sage Publications.

Gee, J. P. (2000). Identity as an analytic lens for research in education. Review of Research in Education, 25, 99-125. doi: 10.3102/0091732X025001099

Glass, C. (2011). 'There's not much room for anything to go amiss': Narrative and artsbased inquiry in teacher education. Issues in Educational Research, 21(2), 130144.

Goffman, E. (1959). The presentation of self in everyday life. Garden City, NY: Doubleday.

Greig, A., Taylor, J., \& MacKay, T. (2007). Doing research with children (2 ${ }^{\text {nd }}$ ed.). London, UK: Sage Publications.

Hamman, D., Wang, E., \& Burley, H. (2013). What I expect and fear next year: Measuring new teachers' possible selves. Journal of Education for Teaching: International research and pedagogy, 39(2), 222-234.

Harfitt, G. J. (2015). From attrition to retention: A narrative inquiry of why beginning teachers leave and then rejoin the profession. Asia-Pacific Journal of Teacher Education, 43(1), 22-35. doi: 10.1080/1359866X.2014.932333

Harré, R. \& Van Langenhove, L. (1999). Position Theory: Moral contexts of intentional action. Oxford, UK: Blackwell.

Hayes R., \& Oppenheim, R. (1997). Constructivism: Reality is what you make it. In T. Sexton \& B. Griffing (Eds.), Constructivist thinking in counseling practice, research and training. New York, NY: Teachers College Press.

Hong, J., \& Greene, B. (2011). Hopes and fears for science teaching: The possible selves of preservice teachers in a science education program. Journal of Science Teacher Education Research Policy and Practice, 22, 491-512.

Howard, S., \& Johnson, B. (2004). Resilient teachers: Resisting stress and burnout. Social Psychology of Education, 7(4), 399-420.

Huber, A. (1995). Transfer of embedded symbolic information between home and school: A grounded theory of how young children develop idiosyncratic responses during the construction of literacy in the classroom (Unpublished $\mathrm{PhD}$ thesis). University of Wollongong, Wollongong, New South Wales. 
Izadinia, M. (2012). A review of research on student teachers' professional identity. British Educational Research Journal, 2012, 1-20. doi:10.1080/01411926.2012.679614.

Jensen, D. (2008). Credibility. In L.M. Given (Ed.), The Sage encyclopaedia of qualitative research methods: Volume one. Los Angeles, CA: Sage Publications.

Johnson, B., Down, B., Le Cornu, R., Peters, J., Sullivan, A. M., Pearce, J., \& Hunter, J. (2015). Promoting early career teacher resilience: A socio-cultural and critical guide to action. London, UK: Routledge.

Kamanos Gamelin, A. (2005). The sand diaries: Visions, vulnerability and self-study. In C. Mitchell, S. Weber \& K. O’Reilly-Scanlon (Eds.), Just who do we think we are? Methodologies for autobiography and self study in teaching (183-192). London, UK: Routledge.

Katz, P., McGinnis, J. R., Hestness, E., Riedinger, K., Marbach-Ad, G., Dai, A., \& Pease, R. (2011). Professional identity development of teacher candidates participating in an informal Science Education internship: A focus on drawings as evidence. International Journal of Science Education, 33(9), 1169-1197. doi:10.1080/09500693.2010.489928

Keats, P. A. (2009). Multiple text analysis in narrative research: Visual, written, and spoken stories of experience. Qualitative Research, 9(2), 181-195.

Kindler, A. M. \& Darras, B. (1994). Artistic development in context: Emergence and development of pictorial imagery in the early childhood years. Visual Arts Research, 20(2), 1-13.

Kress, G. (1997). Before writing: Rethinking the paths to literacy. London, UK: Routledge.

Leitch, R. (2006). Limitations of language: developing arts-based creative narrative in stories of teachers' identities. Teachers and Teaching: theory and practice, 1(5), 549-569.

Lortie, D. C. (1975). Schoolteacher: A sociological study. Chicago, IL: University of Chicago Press.

Lu, Y., \& Curwood, J. S. (2015). Update your status: Exploring pre-service teacher identities in an online discussion group. Asia-Pacific Journal of Teacher Education, 43(5), 438-449. doi: 10.1080/1359866X.2014.960802

Lowenfeld, V., \& Brittain, W. (1987). Creative and mental growth. New York, NY: MacMillan Publishing Company.

Malchiodi, C. (1998). Understanding children's drawings. New York, NY: Guilford Press.

Mansfield, C.F., Beltman, S., \& Price, A. (2014). 'I'm coming back again!': The resilience process of early career teachers. Teachers and Teaching: Theory and Practice, 20(5), 547-567. doi: 10.1080/13540602.2014.937958.

Matthews, W. J., \& Adams, A. (2008). Another reason why adults find it hard to draw accurately. Perception, 37(4), 628-630. doi: 10.1068/p5895 
Moon, B. (2007). Research analysis: Attracting, developing and retaining effective teachers - a global overview of current policies and practices. Paris, France: UNESCO.

Morse, J. (2001). Situating grounded theory within qualitative inquiry. In P. Munhall (Ed.), Nursing research: A qualitative perspective ( $3^{\text {rd }}$ ed.). Boston, MA: Jones and Bartlett.

O’Toole, J., \& Beckett, D., (2013). Educational research: Creative thinking and doing. ( $2^{\text {nd }}$ ed.). South Melbourne: Oxford University Press.

Pearce, J., \& Morrison, C. (2011). Teacher identity and early career resilience: Exploring the links. Australian Journal of Teacher Education, 36(1), 48-59.

Rose, G. (2012). Visual methodologies: An introduction to researching with visual materials ( $3^{\text {rd }}$ ed.). Los Angeles, CA: Sage Publications.

Sfard, A., \& Prusak, A. (2005) Telling identities: In search of an analytic tool for investigating learning as a culturally shaped activity. Educational Researcher, 34(4), 14-22.

Shann, S., Germantse, H. Pittard, L., \& Cunneen, R. (2014). Community and conversation: Tackling beginning teacher doubt and disillusion. Journal of Teacher Education, 42(1), 82-97. doi: 10.1080/1359866X.2013.856000

Siegal, M. (1995). More than words: The generative power of transmediation for learning. Canadian Journal of Education, 20(4), 455-475.

The New London Group. (1996). A pedagogy of multiliteracies: Designing social futures. Harvard Educational Review, 66, 60-92.

Theron, L., Mitchell, C., Smith A., \& Stuart J. (Eds.). (2011). Picturing research: Drawing as visual methodology. Rotterdam, Netherlands: Sense Publishers.

Thwaites, T. (1999). Multiliteracies: A new direction for arts education. Paper presented at the AARE Annual Conference, Melbourne, Australia.

Utley, J., \& Showalter, B. (2007). Preservice elementary teachers' visual images of themselves as mathematics teachers. Focus on Learning Problems in Mathematics, 29(3), 1-14.

Van Manen, M. (1990). Researching lived experience: Human science for an action centered pedagogy. Ontario, Canada: The Althouse Press.

Walkington, J. (2005). Becoming a teacher: Encouraging development of teacher identity through reflective practice. Asia-Pacific Journal of Teacher Education, 33(1), 53-64. doi:10.1080/1359866052000341124

Weber, S., \& Mitchell, C. (1996). Drawing ourselves into teaching: Studying the images that shape and distort teacher education. Teaching and Teacher Education, 12(3), 303- 313.

Wenger, E. (1998). Communities of practice: learning, meaning and identity. Cambridge: Cambridge University Press.

Willis, P. (2002). Don’t call it poetry. The Indo-Pacific Journal of Phenomenology, 2(1), 1-14. 
Wilson, B. (1985). The artistic tower of Babel: Inextricable links between culture and graphic development. Visual Art Research, 11(1), 90-104.

Wright, S. (2007). Young children's meaning-making through drawing and 'telling': Analogies to filmic textual features. Australian Journal of Early Childhood, 32(4), 37-48.

\section{Author Biographies}

Judith Dinham: Holds postgraduate qualifications in education and arts practice. Her research interest is in how arts pedagogies and understandings inform $21^{\text {st }}$ century learning practices.

Beryl Chalk: Researches the narrative of data with particular reference to drama as a multi-layered text and forum for conceptualising and naming 'identity'.

Susan Beltman: Has a background as a school psychologist and teaches in special needs and mentoring units. Current research interests include mentoring and teacher resilience.

Christine Glass: Current research interests include developing understandings of why individuals choose teaching, teacher identity, and the use of art-based research methods.

Bich Nguyen: Works as a research assistant. Her research interests include Systemic Functional Linguistics, Aboriginal education, and language teaching methodology.

Research Ethics: Ethical approval was obtained for the research, from Curtin University's Ethics Committee. Participants' informed consent was sought and granted. Participants gave permission for their de-identified drawings to be included in publications and presentations. 